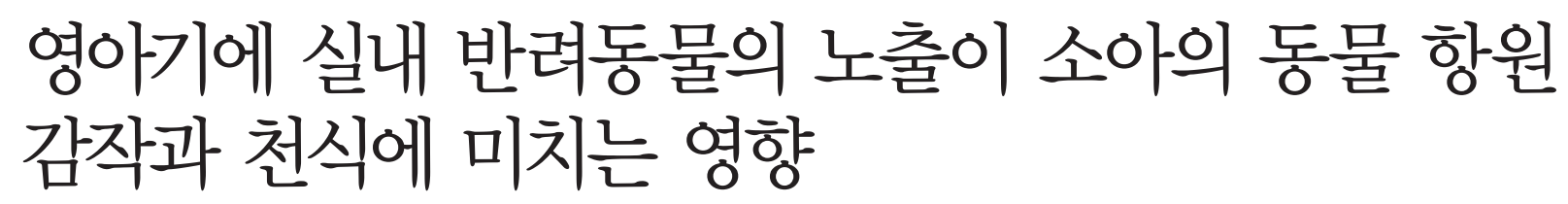

정성수, ${ }^{1}$ 노수란, ${ }^{2}$ 이소연, ${ }^{2}$ 윤지선, ${ }^{3}$ 조현주, ${ }^{4}$ 김영호, ${ }^{2}$ 서동인, ${ }^{5}$ 양송이, ${ }^{6}$ 권지원,,${ }^{7}$ 장광천, ${ }^{8}$ 선용한, ${ }^{9}$ 우성일, ${ }^{10}$ 윤유숙, ${ }^{11}$ 박강서, ${ }^{12}$ 이 은, ${ }^{13}$ 조화진, ${ }^{13}$ 국명희, ${ }^{14}$ 이혜령, ${ }^{14}$ 정혜리, ${ }^{15}$ 김자형, ${ }^{16}$ 김형영, ${ }^{1}$ 정진아, ${ }^{17}$ 우향옥, ${ }^{18}$ 홍수종 ${ }^{2}$

${ }^{1}$ 부산대학교 의과대학 양산부산대학교병원 소아청소년과, ${ }^{2}$ 울산대학교 의과대학 서울아산병원 소아청소년과, ${ }^{3}$ 인천 메디플렉스 세종병원 소아청소년과, ${ }^{4}$ 가톨릭관동대학교 의과대학 국제성모병원 소아청소년과, ${ }^{5}$ 서울대학교 의과대학 서울대학교병원 소아청소년과, ${ }^{6}$ 한림대학교 의과대학 한림대학교성심병원 소아청소년과, ${ }^{7}$ 서울대학교 의과대학 분당서울대학교병원 소아청소년과, ${ }^{8}$ 국민건강보험 일산병원 소아청소년과, ${ }^{9}$ 가천대학교 의과대학 가천대학교길병원 소아청소년과, ${ }^{10}$ 충북대학교 의과대학 충북대학교병원 소아청소년과, ${ }^{11}$ 가톨릭대학교 의과대학 가톨릭대학교 대전성모병원 소아청소년과, ${ }^{2}$ 전주 예수병원 소아청소년과, ${ }^{13}$ 전남대학교 의과대학 전남대학교병원 소아청소년과, ${ }^{14}$ 광주보훈병원 소아청소년과, ${ }^{15}$ 가톨릭대학교 의과대학 대구가톨릭대학교병원 소아청소년과, ${ }^{16}$ 경상대학교 의과대학 울산대학교병원 소아청소년과, ${ }^{17}$ 동아대학교 의과대학 동아대학교병원 소아청소년과, ${ }^{18}$ 경상대학교 의과대학 경상대학교병원 소아청소년과

\title{
Indoor pet ownership in infancy is a risk factor for the development of sensitization to pets and asthma in childhood
}

\begin{abstract}
Sungsu Jung, ${ }_{1}$ Soo Ran Noh, ${ }^{2}$ So-Yeon Lee, ${ }^{2}$ Jisun Yoon, ${ }^{3}$ Hyun-Ju Cho, ${ }^{4}$ Young-Ho Kim, ${ }^{2}$ Dong In Suh, ${ }^{5}$ Song-I Yang, ${ }^{6}$ Ji-won Kwon, ${ }^{7}$ Gwang Cheon Jang, ${ }^{8}$ Yong Han Sun, ${ }^{9}$ Sung-II Woo, ${ }^{10}$ You-Sook Youn, ${ }^{11}$ Kang Seo Park, ${ }^{12}$ Eun Lee, ${ }_{13}^{13}$ Hwa Jin Cho, ${ }^{13}$ Myung-Hee Kook, ${ }^{14}$ Hye Ryoung Yi, ${ }^{14}$ Hai Lee Chung, ${ }^{15}$ Ja Hyeong Kim, ${ }^{16}$ Hyung Young Kim, ${ }^{1}$ Jin A Jung, ${ }^{17}$ Hyang-Ok Woo, ${ }^{18}$ Soo-Jong Hong ${ }^{2}$

${ }^{1}$ Department of Pediatrics, Pusan National University Yangsan Hospital, Pusan National University School of Medicine, Yangsan; ${ }^{2}$ Department of Pediatrics, Childhood Asthma Atopy Center, Environmental Health Center, Asan Medical Center, University of Ulsan College of Medicine, Seoul; ${ }^{3}$ Department of Pediatrics, Mediplex Sejong Hospital, Incheon; ${ }^{4}$ Department of Pediatrics, International St. Mary's hospital, Catholic Kwandong University, Incheon; ${ }^{5}$ Department of Pediatrics, Seoul National University Hospital, Seoul National University College of Medicine, Seoul; ${ }^{6}$ Department of Pediatrics, Hallym University Sacred Heart Hospital, Hallym University College of Medicine, Anyang; ${ }^{7}$ Department of Pediatrics, Seoul National University Bundang Hospital, Seoul National University College of Medicine, Seongnam; ${ }^{8}$ Department of Pediatrics, National Health Insurance Service Ilsan Hospital, Goyang; ${ }^{9}$ Department of Pediatrics, Gachon University Gil Medical Center, Incheon; ${ }^{10}$ Department of Pediatrics, Chungbuk National University Hospital, Chungbuk National University College of Medicine, Cheongju; " ${ }^{11}$ Departments of Pediatrics, Daejeon St. Mary's Hospital, College of Medicine, The Catholic University of Korea, Daejeon; ${ }^{12}$ Department of Pediatrics, Presbyterian Medical Center, Jeonju; ${ }^{13}$ Department of Pediatrics, Chonnam National University Hospital, Chonnam National University Medical School, Gwangju; ${ }^{14}$ Department of Pediatrics, Gwangju Veterans Hospital, Gwangju; ${ }^{15}$ Department of Pediatrics, Catholic University of Daegu School of Medicine, Deagu; ${ }^{16}$ Department of Pediatrics, University of Ulsan College of Medicine, Ulsan; ${ }^{17}$ Department of Pediatrics, Dong-A University Hospital, Dong-A University College of Medicine, Busan; ${ }^{18}$ Department of Pediatrics, Gyeongsang National University College of Medicine, Jinju, Korea
\end{abstract}

Purpose: It is controversial whether indoor pet exposure is either a risk or protective factor developing sensitization to pet allergens or asthma. Therefore, we investigated whether indoor pet ownership entails a risk for the development of asthma and sensitization in childhood.

Methods: The Panel Study of Korean Children (PSKC) is a general-population-based birth cohort study that recruited 2,078 motherbaby dyads in Korea between April and July of 2008. Among 1,577 children who were followed up in 2015, 559 underwent skin prick tests, spirometry and bronchial provocation tests using Provocholine. Having a cat or a dog and the prevalence of asthma were evaluated by using self-reported questionnaires and physicians' medical records.

Results: During infancy, the rate of dog ownership was $4.5 \%$ (71 of 1,574) and that of cat ownership was $0.5 \%$ (8 of 1,574). Of the subjects, $7.9 \%(n=109)$ currently had at least 1 dog and $2.5 \%(n=34)$ had at least 1 cat. Pet ownership during infancy was associated with sensitization to cats or dogs (adjusted odds ratio [aOR], 4.24; 95\% confidence interval [Cl], 1.29-13.98), wheezing within 12 months (aOR, 5.56; 95\% Cl, 1.65-18.75) and current asthma (wheezing episode in the last 12 months+diagnosed asthma by physicians) (aOR, 6.36; 95\% Cl, 1.54-26.28). In contrast, pet ownership during the last 12 months was not associated with sensitization to cats or dogs or current asthma.

Conclusion: Indoor pet exposure during infancy can be critical for developing sensitization to cats or dogs and asthma in childhood. Avoidance of pet exposure in early life may reduce sensitization to cats or dogs and development of asthma. (Allergy Asthma Respir Dis 2019;7:99-105)

Keywords: Pets, Infant, Asthma, Allergens

Correspondence to: Soo-Jong Hong (iD https://orcid.org/0000-0003-1409-2113

Department of Pediatrics, Childhood Asthma Atopy Center, Asan Medical Center College of Medicine,

Ulsan University, 88 Olympic-ro 43 gil, Songpa-gu, Seoul 05505, Korea

Tel: +82-2-3010-3379, Fax: +82-2-473-3725, E-mail: sjhong@amc.seoul.kr

- This study was supported by a fund (2015-ER6601-00) from the Research of Korea Centers for Disease Control and Prevention. This study was also funded by the Panel Study of Korean Children (PSKC) of the Korea Institute of Child Care and Education (KICCE) and developed based on the PSKC data set of 2008, 2013, 2014, and 2015.

Received: March 19, 2019 Revised:April 3, 2019 Accepted: April 4, 2019

(C) 2019 The Korean Academy of Pediatric Allergy and Respiratory Disease The Korean Academy of Asthma, Allergy and Clinical Immunology This is an Open Access article distributed under the terms of the Creative Commons Attribution Non-Commercial License (http://creativecommons.org/licenses/by-nc/4.0/). 


\section{서 론}

실내 환경 물질은 다양한 방식으로 천식의 발생에 영향을 미칠 수 있다. ${ }^{1}$ 반려동물은 중요한 실내 환경 항원 중에 하나이지만, ${ }^{2}$ 이 전 연구 결과에서는 실내 반려동물을 보유하는 것이 반려동물 항 원에 감작과 천식에 어떠한 영향을 미치는지에 대해 일치되지 않는 결과를 보이고 있다.3-5 고양이에 대한 이전 연구들을 살펴보면, 일 부 연구들에서는 유아기의 반려묘의 노출이 고양이 항원 감작을 막는 데 영향을 미치는 결과를 보인 반면, ${ }^{6}$ 다른 연구들에서는 만 1 세 이전에 반려묘의 노출이 반복성 천명과 연관성이 있는 것으로 나왔다. 13 개의 출생 코호트를 체계적으로 분석한 연구 결과에서 는 출생초기 반려견에 노출되는 것과 천식과의 연관성은 없는 것 으로 보고하였다. ${ }^{8} 11$ 개의 유럽 출생 코호트 분석에서도 출생 후 첫 2년 동안 반려동물에 노출되는 것과 6-10세 사이에 발생한 천식과 특별한 연관성을 보이지 않았다. ${ }^{6}$ 그러나 이러한 연구들은 하위집 단의 특성에 따른 차이를 고려하지 않은 분석 결과였다. 미국 출생 코호트 연구에서는 집단의 특성에 따라 소그룹으로 분류하여 분 석을 시행하였고, 만 1 세 이전에 실내에서 반려견과 같이 생활한 아 이들을 대상으로 특성이 다른 소그룹에 따라 3-6세 천식 발생에 대한 영향이 어떻게 다른지 분석하였다. ${ }^{9}$ 이 분석 결과 알레르기질 환과 출생 초기 반려동물 노출과의 연관성은 소그룹의 특성과 이 에 영향을 미치는 다양한 인자들에 따라 다양할 수 있음을 보였다. 이러한 점을 고려하여 출생 초기 반려동물 보유와 알레르기질환의 연관성을 분석할 때, 반려동물을 키우는 문화와 환경적 요인, 반려 동물의 종류와 수를 고려해야 할 것으로 사료된다. 최근 우리나라 주거환경과 문화적 생활양식이 변화하면서, 실내 반려동물을 보유 하는 세대 수가 급격히 증가하고 있고, ${ }^{10,11}$ 이에 따라 반려동물이 알 레르기질환에 어떠한 영향을 미치는지에 대하여 새로운 연구가 필 요한 시점이다. 그럼에도 불구하고 출생 초기 반려동물에 대한 노 출이 한국 아동의 천식에 어떤 영향을 미치는지에 대한 연구는 거 의 없다. 이 연구는 한국아동패널연구를 통하여 우리나라 소아에 서 반려견과 반려묘의 보유 현황을 조사하고 반려견과 반려묘를 키운 시기에 따라, 반려동물 항원의 감작과 기관지과민성, 천식 증 상에 어떻게 영향을 주는지에 대해 분석하였다.

\section{대상 및 방법}

\section{1. 대상}

한국아동패널연구(Panel Study on Korean Children, PSKC)는 일반 인구 집단 출생 코호트 연구로 2 단계의 층화 무작위 표본 추 출을 통해 한국의 6 개 지역에서 2,078 쌍의 산모와 신생아 대상군을 모집하였다. ${ }^{12} 1$ 차 표본 추출은 매년 500 건 이상의 분만이 이루어지 는 30 개의 산부인과병원에서 시행되었다. 2 차 표본 추출은 2008 년
4월부터 7월까지 이 병원에서 출산이 이루어진 대상군으로 이루어 졌다. 한국아동패널연구는 종단 인구 통계 특성, 아동 발달, 보육 행동 및 교육을 조사하기 위해 고안된 연구로서, 대상군들을 매년 1회 추적 조사하였다. 2013년도부터 이 추적조사에 알레르기질환 과 관련된 설문지가 포함되었다. 2015년(만 7세)에 추적 조사를 받 은 1,577 명의 아동(남자 809 명, 여자 768 명) 중 554 명이 15 개 주요 병원을 방문하여 의사에 의한 신체 진찰, 알레르기 피부단자시험, 프로보콜린 기관지유발검사를 시행받았다. 이 연구는 서울아산병 원 임상연구윤리심의위원회(Institutional Review Board, IRB)로 부터 승인받아 진행되었다(IRB 승인 번호: 2015-0907). 모든 대상 군의 보호자들에게 연구에 대한 자세한 설명을 하고 서면동의를 받 았다.

\section{2. 반려동물 보유에 대한 평가}

2013년 보호자 설문지를 통하여 대상군 나이 만 5세에 임신 때 부터 생후 12 개월 이내에 반려동물의 보유 여부를 조사하였고, 2015년 보호자 설문지를 통하여 대상군 나이 만 7세에 최근 12개 월 이내에 반려동물 보유 여부를 조사하였다. 임신 때부터 생후 12 개월 이내에 반려견을 보유한 대상군은 71 명 $(4.5 \%, 71 / 1,574)$, 반려 묘를 보유한 대상군은 8 명 $(0.5 \%, 8 / 1,574)$ 으로 대상군의 수가 적어 서, 반려견과 반려묘 중 한 종류라도 보유한 경우를 반려동물 보유 로 정의하고 분석을 진행하였다. 2015년(7세) 의사기록지를 통하여 천식의 진단력과 최근 12 개월 이내에 천명음을 경험했는지 여부를 조사하였다. 현증 천식의 정의는 2015년(7세) 의사기록지를 통하여 출생 후 지금까지 의사로부터 천식을 진단받은 적이 있으면서 지난 12 개월 이내에 천명음을 경험한 대상군으로 정의하였다.

\section{3. 알레르기 피부단자시험과 기관지유발검사}

알레르기 피부단자시험은 18 종의 알레르기 항원들(Dermatophagoides pteronyssinus, Dermatophagoides farinae, dog epithelia, cat epithelia, cockroaches, Alternaria alternata, Aspergillus fumigatus, grass pollen, ragweed, mugwort, alder, oak, Japanese hop, birch, hazel, peanuts, milk, egg whites)과 히스타민과 식염수를 각각 양 상 대조군과 음성 대조군으로 하여 검사를 진행하였다. 피부단자 시험 양성은 히스타민에 의하여 유발된 팽진이 $3 \mathrm{~mm}$ 이상이고, 히 스타민에 의해 유발된 팽진 크기보다 같거나 큰 경우로 정의하였다. 아토피의 정의는 피부단자시험에서 하나 이상의 알레르기항원에 양성반응을 보인 경우로 하였다.13

기관지유발검사는 국제 표준화된 메타콜린 및 운동유발검사의 지침에 따라 수행되었다. ${ }^{14}$ 검사를 위해 프로보콜린(methacholine chloride USP, Methapharm Inc., Brantford, ON, Canada)은 완충 용액과 섞어 5 가지의 농도 $(0.0625,0.25,1,4,16 \mathrm{mg} / \mathrm{mL})$ 로 준비되 었다. 대상군들은 최대 폐용량에 도달할 때까지 생리식염수를 입 
으로 흡입한 다음, 약 5 초 동안 숨을 유지하였다. 90 초 후에 1 초간 강제호기량(forced expiratory volume in 1 second, $\mathrm{FEV}_{1}$ )을 기준으 로 폐활량을 측정하였다. 각 농도의 프로보콜린을 흡입하고 $\mathrm{FEV}_{1}$ 을 기준치와 동일한 방식으로 측정한 다음 $\mathrm{FEV}_{1}$ 이 기준치에 비해 $20 \%$ 이상 감소하거나 대상군이 최종 프로보콜린 농도 $16 \mathrm{mg} / \mathrm{mL}$ 에 도달할 때까지 검사를 반복하였다. 또한 기준선에서 $\mathrm{FEV}_{1}$ 이 $20 \%$ 이상 감소한 프로보콜린의 농도를 계산하였다. 기관지과민성 은 provocative concentration of methacholine causing a $20 \%$ fall in $\mathrm{FEV}_{1}\left(\mathrm{PC}_{20}\right)<16 \mathrm{mg} / \mathrm{mL}$ 또는 $\mathrm{PC}_{20}<8 \mathrm{mg} / \mathrm{mL}$ 로 정의하였다.

\section{4. 통계 분석}

통계 분석은 IBM SPSS Statistics ver. 23.0 (IBM Co., Armonk, $\mathrm{NY}, \mathrm{USA}$ )을 이용하였다. 알레르기검사를 완료한 그룹과 알레르기 검사를 수행하지 않은 그룹을 비교하기 위하여 카이제곱 검정이 사용되었다. 반려동물의 보유가 천식 발병 위험과 반려동물 항원 의 감작의 위험을 높이는지를 분석하기 위하여 로지스틱 회귀분석 이 시행되었고 교차비(odds ratio, OR)와 $95 \%$ 신뢰구간을 계산하 기 위해 성별, 미숙아 출생 여부, 부모의 알레르기질환력, 산모의 교
육 수준, 간접흡연력이 보정변수로 사용되었다. $P$ 값이 0.05 미만일 때 통계적으로 유의하다고 판단하였다.

\section{결 과}

\section{1. 대상군의 특성}

한국아동패널연구에서 2008년 모집된 2,078명의 대상군 중 1,577 명의 대상군이 2015년(만 7세)까지 추적되었다. 1,577 명의 대 상군 중 남자아이가 814명이었고 여자아이가 772명이었다. 이들 중 642 명이 병원에 방문하였고, 554 명의 대상군이 최종적으로 알레르 기 피부단자시험과 기관지유발검사를 완료할 수 있었다(Fig. 1).

생후 첫 12 개월 동안 반려동물의 보유 여부, 최근 12 개월 이내에 반려동물 보유 여부, 모유수유, 간접흡연(부모의 흡연력), 부모의 알레르기질환 병력, 천식의 진단력, 최근 12 개월 이내에 천명음 발 생 여부, 현증 천식 여부 등을 비교하였을 때 알레르기검사를 받은 그룹 $(\mathrm{n}=554)$ 과 알레르기검사를 받지 않은 그룹 $(\mathrm{n}=1,023)$ 사이에 의미 있는 차이를 보이지 않았다. 그러나 생후 36 개월 이전에 모세 기관지염의 발생 여부와 알레르기비염 진단력, 아토피피부염의 진

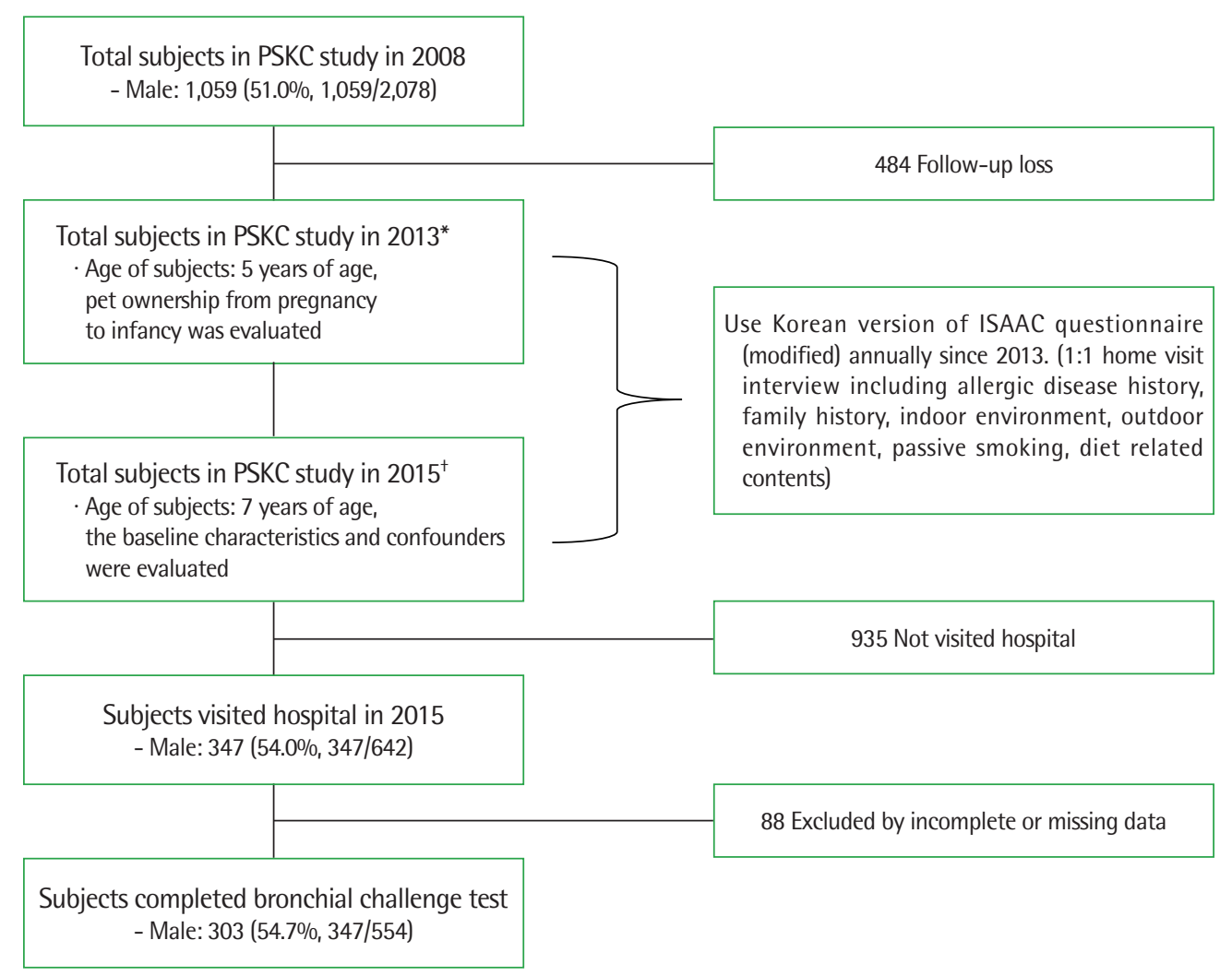

Fig. 1. Study population. PSKC, Panel Study of Korean Children; ISAAC, International Society for Augmentative and Alternative Communication. *The rate of pet ownership from pregnancy to infancy was evaluated by a 2013 questionnaire. ${ }^{\dagger} 2015$ questionnaire was used to identify the baseline characteristics and confounders (sex, body mass index, preterm birth, possession of pet within the last 12 months, breastfeeding, secondhand smoke, parental allergic disease, history of bronchiolitis, and maternal education level). 
단력은 알레르기검사를 받은 그룹이 통계적으로 유의하게 높았다 $(P=0.047, P<0.001, P<0.001)$ (Table 1).

\section{2. 반려동물의 보유와 천식의 유병률}

임신 때부터 출생 이후 12 개월 내에 반려견을 보유한 대상군은 71 명(4.5\%)이었고, 반려묘는 8 명(0.5\%)이었다. 최근 12 개월 이내에 반려동물을 키우는 정도는 109명(7.9\%)이 적어도 한 마리의 반려 견을, 34명(2.5\%)은 적어도 한 마리의 반려묘를 키우고 있었다. 임 신 때부터 출생 이후 12 개월 내에 반려동물 보유(반려견과 반려묘

Table 1. Characteristics of the enrolled subjects

\begin{tabular}{|c|c|c|c|}
\hline Characteristic & $\begin{array}{l}\text { Subjects completed } \\
\text { allergic evaluation } \\
\qquad(n=554)\end{array}$ & $\begin{array}{l}\text { Excluded by } \\
\text { missing data } \\
(n=1,023)\end{array}$ & $P$-value ${ }^{*}$ \\
\hline Male sex & $303(54.7)$ & $506(49.5)$ & 0.047 \\
\hline Body mass index $\left(\mathrm{kg} / \mathrm{m}^{2}\right)$ & $17.02 \pm 2.5$ & $16.9 \pm 2.9$ & 0.829 \\
\hline Pet ownership in infancy & $30(5.4)$ & $36(3.5)$ & 0.098 \\
\hline Current pet ownership & $40(7.2)$ & $91(8.9)$ & 0.245 \\
\hline Breast feeding & $329(59.4)$ & $617(60.3)$ & 0.625 \\
\hline Secondhand smoking & $251(45.3)$ & $465(45.5)$ & 0.550 \\
\hline Parent allergy history & $286(51.6)$ & $469(45.8)$ & 0.206 \\
\hline Bronchiolitis ever (<36 mo) & $132(23.8)$ & $194(19.0)$ & 0.025 \\
\hline Asthma diagnosis & $26(4.7)$ & $29(2.8)$ & 0.056 \\
\hline Wheezing within $12 \mathrm{mo}$ & $30(5.4)$ & $61(6.0)$ & 0.643 \\
\hline Current asthma $^{\dagger}$ & $9(1.6)$ & $15(1.5)$ & 0.812 \\
\hline Allergic rhinitis diagnosis & $301(54.3)$ & 407 (39.8) & $<0.001$ \\
\hline Atopic dermatitis diagnosis & $141(25.5)$ & $171(16.7)$ & $<0.001$ \\
\hline
\end{tabular}

Values are presented as number (\%) or mean \pm standard deviation.

${ }^{*}$ Chi-square test. ${ }^{\dagger}$ Current asthma was defined as both physician-diagnosed asthmaever and a wheezy episode during the prior 12 months.
중 한 마리라도 기르는 경우)는 대상군의 $4.8 \%(76 / 1,574)$ 이었고, 최 근 12 개월 이내에 반려동물을 보유한 대상군은 $8.4 \%(131 / 1,563)$ 였 다. 2015 년 의사기록지에서 출생 후 지금까지 의사로부터 천식을 진 단받은 병력이 있는 경우는 $8.1 \%(44 / 544)$ 였다.

\section{3. 반려동물의 보유 시기와 7세 천식 증상과의 연관성}

임신 때부터 출생 이후 12 개월 내에 반려동물 보유 여부와 2015년 의사기록지로 조사된 12 개월 이내에 천명음 발생과 현증 천식의 연 관성을 분석한 결과 교차비는 각각 5.56 (95\% confidence interval [CI], 1.65-18.75) 및 6.36 (95\% CI, 1.54-26.28)으로 임신 때부터 출 생 이후 12 개월 내에 반려동물 보유가 만 7 세 아동의 최근 12 개월 이내의 천명 발생과 현증 천식의 위험 인자로 분석되었다. 그러나 최근 12 개월 이내의 반려동물의 보유는 최근 12 개월 이내의 천명 이나 현증 천식과 특별히 관련성이 없었다(Table 2).

\section{4. 반려동물과 항원 감작과의 연관성}

임신 때부터 출생 이후 12 개월 내에 반려동물을 키우는 경우 만 7세의 개 또는 고양이 항원에 대한 감작의 위험도가 증가하였다 (adjusted OR [aOR], 4.24; 95\% CI, 1.29-13.98). 그러나 최근 12개월 이내에 반려동물을 키우는 경우 개나 고양이 항원 감작과 연관성 이 없었다. 임신 때부터 출생 이후 12 개월 내에 반려동물 보유와 최 근 12 개월 이내에 반려동물 보유는 7세 아동의 아토피 연관성을 보 이지 않았다(Table 3).

\section{5. 반려동물의 보유와 기관지과민성과의 연관성}

임신 때부터 출생 이후 12 개월 내에 반려동물 보유는 $\mathrm{PC}_{20}<$ $16 \mathrm{mg} / \mathrm{mL}$ 를 기관지과민성으로 정의하였을 때는 연관성을 보이지

Table 2. The association between pet ownership from pregnancy to infancy or during the last 12 months and asthma symptoms at age of 7

\begin{tabular}{|c|c|c|c|c|c|}
\hline \multirow{2}{*}{ Variable } & \multirow{2}{*}{$\begin{array}{l}\text { Whole subjects } \\
\text { No./total No. (\%) }\end{array}$} & \multicolumn{2}{|c|}{ Pet ownership from pregnancy to infancy (+) } & \multicolumn{2}{|c|}{ Current pet ownership (+) } \\
\hline & & No./total No. $(\%)$ & $\mathrm{aOO} *(95 \% \mathrm{Cl})$ & No./total No. $(\%)$ & $\mathrm{aOR} \mathrm{R}^{*}(95 \% \mathrm{Cl})$ \\
\hline Asthma diagnosis. ever & $42 / 554(7.6)$ & $4 / 31(12.9)$ & $2.99(0.88-10.15)$ & $2 / 38(5.3)$ & $0.89(0.20-4.07)$ \\
\hline Wheezing within $12 \mathrm{mo}$ & $27 / 554(4.9)$ & 4/31 (12.9) & $5.56(1.65-18.75)$ & 1/38 (2.6) & $0.60(0.08-4.73)$ \\
\hline Current asthma $^{\dagger}$ & 17/554 (3.1) & $3 / 31(9.7)$ & $6.36(1.54-26.28)$ & 1/38 (2.6) & $0.97(0.12-7.93)$ \\
\hline
\end{tabular}

aOR, adjusted odds ratio; $\mathrm{Cl}$, confidence interval.

${ }^{*}$ Adjusted for sex, preterm birth, body mass index, patents' history of allergic disease, maternal educational level and secondhand smoking. ${ }^{\dagger}$ Current asthma was defined as both physician-diagnosed asthma-ever and a wheezy episode during the prior 12 months.

Table 3. The association between pet ownership from pregnancy to infancy or during the last 12 months and allergic sensitization to cats or dogs at age of 7

\begin{tabular}{|c|c|c|c|c|c|c|c|}
\hline \multirow{2}{*}{ Variable } & \multirow{2}{*}{$\begin{array}{l}\text { Whole subjects } \\
\text { No./total No. (\%) }\end{array}$} & \multicolumn{3}{|c|}{ Pet ownership from pregnancy to infancy (+) } & \multicolumn{3}{|c|}{ Current pet ownership (+) } \\
\hline & & No./total No. (\%) & OR (95\% Cl) & $\mathrm{aOR}^{*}(95 \% \mathrm{Cl})$ & No./total №. (\%) & $\mathrm{OR}(95 \% \mathrm{Cl})$ & $\mathrm{aOR}{ }^{*}(95 \% \mathrm{Cl})$ \\
\hline Sensitization to cat or dog & $144 / 554(26.0)$ & $11 / 31(35.5)$ & $4.20(1.60-11.0)$ & 4.24 (1.29-13.98) & 12/38 (31.6) & $0.66(0.15-2.83)$ & $0.38(0.05-2.96)$ \\
\hline Any atopy by SPT & $259 / 554(46.8)$ & 17/31 (54.8) & $1.37(0.67-2.80)$ & $1.48(0.61-3.58)$ & 12/38 (31.6) & $0.53(0.28-1.00)$ & $0.60(0.28-1.29)$ \\
\hline
\end{tabular}

$\mathrm{SPT}$, skin prick test; $\mathrm{OR}$, odds ratio; $\mathrm{aOR}$, adjusted odds ratio; $\mathrm{Cl}$, confidence interval.

${ }^{*}$ Adjusted for sex, preterm birth, body mass index, patents' history of allergic disease, maternal educational level and secondhand smoking. 
Table 4. The association between pet ownership from pregnancy to infancy or during the last 12 months and bronchial hyperresponsiveness (BHR) by provocholine challenge test at age of 7

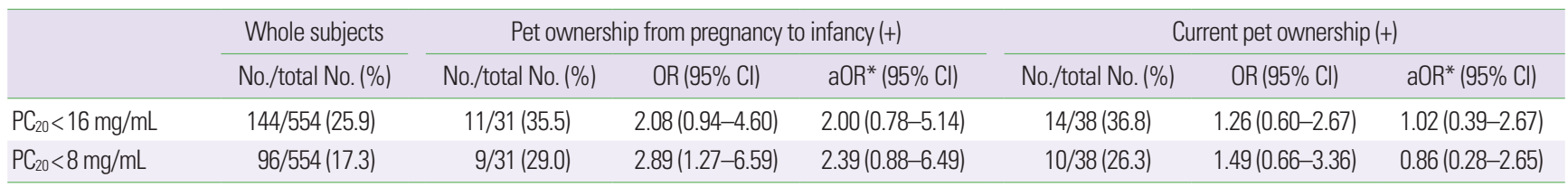

$\mathrm{OR}$, odds ratio; aOR, adjusted odds ratio; $\mathrm{Cl}$, confidence interval.

${ }^{*}$ Adjusted for sex, preterm birth, body mass index, patents' history of allergic disease, maternal educational level and secondhand smoking.

Table 5. The association between pet ownership from pregnancy to infancy or during the last 12 months and allergic sensitization to cats or dogs at age of 7

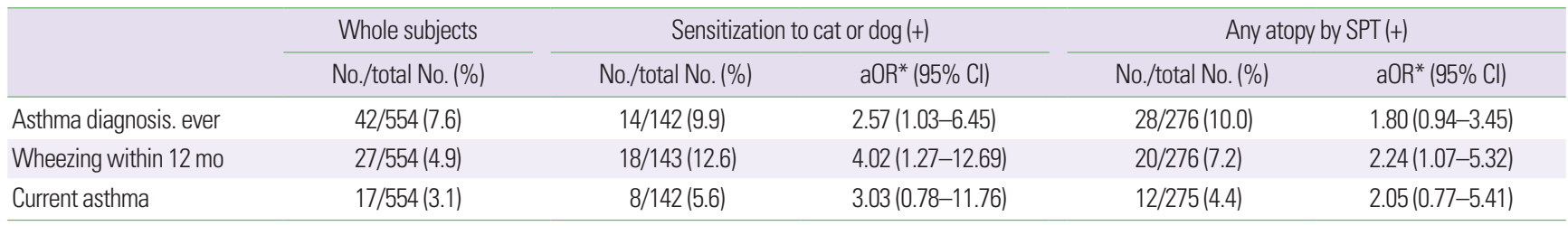

aOR, adjusted odds ratio; $\mathrm{Cl}$, confidence intervals.

*Adjusted for sex, preterm birth, body mass index, patents' history of allergic disease, maternal educational level and secondhand smoking.

않았지만, 기관지과민성을 $\mathrm{PC}_{20}<8 \mathrm{mg} / \mathrm{mL}$ 로 정의하였을 때, 임신 때부터 출생 이후 12 개월 내에 반려동물 보유와 연관성을 보였으 나(OR, 2.89; 95\% CI, 1.27-6.59), 보정변수로 보정하였을 때에는 통 계적으로 유의하지 않았다 $(\mathrm{aOR}, 2.39 ; 95 \% \mathrm{CI}, 0.88-6.49)$. 최근 12 개월 동안 반려동물 보유는 기관지과민성과 관련성을 보이지 않았 다(Table 4).

\section{6. 개 또는 고양이 항원 감작과 천식과의 연관성}

개 또는 고양이 항원에 대한 감작은 천식의 진단력과 연관성을 보 였고(aOR, 2.57; 95\% CI, 1.03-6.45), 최근 12개월 이내 천명음 발생 여부와 연관성을 보였다(aOR, 4.02; 95\% CI, 1.27-12.69) (Table 5).

\section{고 찰}

최근 우리나라에서도 반려동물을 키우는 경우가 급격히 증가하 고 있지만 반려동물의 노출과 천식과 같은 알레르기질환과의 관련 성에 대한 국내 연구는 부족한 실정이다. 이 연구에서는 반려견 또 는 반려묘를 키우는 경우, 개 또는 고양이 항원에 대한 감작과 천식 증상 및 기관지과민성에 대한 위험성이 증가하는지에 대하여 일반 인구 집단 기반 출생 코호트를 통하여 분석하였다. 이 연구 결과, 임 신 때부터 출생 이후 12 개월 내에 반려견 또는 반려묘를 보유하였을 때 7세 아동에서 천식 증상의 위험도가 증가하였다. 또한 임신 때부 터 출생 이후 12 개월 내에 반려동물의 보유가 7 세 아동에서 개나 고양이 항원에 대한 감작의 위험을 증가시킴을 확인하였다. 그리고 개 또는 고양이 항원에 대한 감작은 천식의 진단력과 최근 12 개월 이내 천명음 발생 여부와 연관성을 보였다. 그러나 만 7세 아동에서
최근 12 개월 이내에 반려견이나 반려묘를 키우는 경우, 최근 12 개 월 이내 천명음 발생이나 현증 천식에 영향을 미치지 않았다. 이 연 구 결과는 임신 때부터 출생 이후 12 개월 내에 반려견이나 반려묘 에 대한 노출이 학동기 아동의 알레르기항원 감작이나 천식 증상 발생에 영향을 주는 중요한 시기일 수 있음을 시사한다. 따라서 임 신 때부터 출생 이후 12 개월 내에 반려동물의 보유를 피하는 것이 우리나라 아동에서 개나 고양이 항원 감작과 학동기 천식 증상 발 생을 줄일 수 있을 것으로 생각한다.

이전 코호트 연구에서 반려동물의 보유와 반려동물 항원의 감 작, 천식의 발생과의 연관성은 일치되지 않는 결과를 보였다. 스웨 덴의 전향적 출생 코호트 연구에서 출생 초기 반려묘의 보유가 4 세 아동에서 고양이 항원 감작의 위험성을 증가시켰지만 천식 발 생과는 연관성을 보이지 않았다. ${ }^{15}$ 하지만 이 연구는 기관지과민성 검사를 시행하지 않았으며, 만 4세는 천식을 진단하기에는 이른 나 이라는 문제점을 가지고 있다. 영국의 출생 코호트 연구에서는 임 신 중과 유아기의 반려동물과 천식과의 연관성을 이 연구에서 여 러 종류의 반려동물(고양이, 개, 토끼, 설치류, 조류, 물고기)을 포함 하여 만 7세까지 여러 시점의 폐기능을 포함하여 분석하였다. ${ }^{16}$ 고 양이를 반려동물로 보유하였을 때는 폐기능에 대한 영향은 없었 고, 천명음 발생의 위험성을 감소시켰다. 하지만 이 연구에서도 기 관지과민성을 평가하지는 않았다. 네덜란드에서 2,729명의 7-12세 소아를 대상으로 시행한 연구에서는, ${ }^{4}$ 생후 2 세 이전에 반려동물 의 보유와 천식의 진단력, 개와 고양이 항원의 감작, 기관지과민성 과의 연관성이 없었다. 그러나 이 연구에서는 반려 동물의 노출 기 간을 임신 때부터 출생 이후 12 개월 내로 더 엄격히 정의하여 임신 중과 출생 초기의 반려동물의 노출이 알레르기질환에 어떠한 영 
향을 미치는지에 대하여 조금 더 초점을 맞출 수 있었다. 이와같이 서로 다른 결과를 초래하는 것은 반려동물을 키우는 실내외 환경 의 차이와 인종적인 차이, 생활 환경의 차이 등을 고려하고, 특히 키 우기 시작한 시점과 동시에 키우는 기간, 키우는 마릿수와 과정에 질환 발생의 여부가 미치는 영향 등도 고려한 연구가 필요할 것으 로 기대된다.

이 연구에서는 반려동물을 최근 12 개월 이내에 키우는 경우와 천명 증상의 발생, 현증 천식과 알레르기항원에 대한 감작과 연관 성이 관찰되지 않았다. 그러나 이 연구 결과를 해석할 때, 이미 반려 동물에 대하여 알레르기감작이 발생하여 증상이 나타난 아이들 은 현재 반려동물을 기르지 않고 있을 가능성을 고려해야 하고 또 한 키우는 기간이 짧은 경우로 생각되므로 최근 12 개월 이내 반려 동물을 키우는 것이 반려동물 항원에 대한 알레르기감작이나 천 식 증상과 관련이 없다고 결론을 내릴 수는 없다.

반려동물의 종류뿐만 아니라 보유하고 있는 반려동물의 숫자도 반려동물이 알레르기질환에 대한 영향을 미치는 데에 고려해야 할 요소이다. ${ }^{17-19}$ 두 개의 스웨덴 코호트를 분석한 연구에서 ${ }^{19}$ 7-9세 아동에서 유아기에 반려동물을 많이 보유할수록 알레르기질환 발 생이 감소하는 경향을 보여줌으로써 많은 양의 항원에 어린 나이 에 노출됨으로써 면역관용을 획득하였을 가능성을 제시하고 있 다. 이 연구에서는 임신 때부터 출생 이후 12 개월에 반려동물을 보 유한 76명 중 대다수인 55명(72.3\%)이 한 마리의 반려동물만 보유 하여, 반려동물의 수에 따른 영향을 분석하기는 어려울 것으로 생 각되지만, 최근 국내에서 여러 마리의 반려동물을 키우는 집들이 증가하고 있기에 앞으로 이런 영향에 대한 연구도 필요할 것으로 기대된다.

이 연구 결과, 알레르기질환 발생의 기전을 생후 12 개월 이내에 반려동물을 기르는 것이 동물 항원에 대한 감작을 일으키고, $\mathrm{Th} 2$ 세포의 반응을 활성화하여 이후 천식 발생에 영향을 미치는 것으 로 생각할 수 있다. 하지만 알레르기항원에 대한 노출이 차단항체 의 생성을 유도하는 변형된 Th2 반응을 일으킬 수 있어 상반된 결 과를 보일 수 있다. 이러한 양면적인 현상을 설명하기 위해서 향후 가설 근거로 잘 계획된 전향적인 연구가 필요할 것으로 생각한다.

이번 연구는 일반 인구 집단의 출생 코호트를 기반으로 한 분석 결과라는 점에서 큰 강점을 가지고 있다. 그러나 연구의 대상 숫자 가 많지 않으며, 병원에 방문한 대상군이 병원에 방문하지 않은 대 상군에 비하여 알레르기비염, 아토피피부염의 유병률이 높고, 36 개 월 이전에 세기관지염 과거력의 비율이 더 높았다(Table 1). 이러한 점들은 이 연구에서 우리나라 아동의 천식과 기관지과민성의 유병 률이 실제 일반인보다 조금 더 과대평가되었을 가능성이 있음을 시사한다. 그리고 반려동물의 보유 여부에 대한 정보는 보호자 설 문지를 통하여 수집되어 회상 오류가 발생했을 가능성이 있다. 또 한 이 연구에서는 대상군 수가 많지 않아서 개와 고양이를 별도로
분석하지 못하였고, 반려 동물의 노출의 강도, 노출 기간 등의 영향 을 조사하지 못한 한계점이 있다. 앞으로 이에 대한 추가 연구가 필 요하다. 그러나 이 연구에서는 의사가 직접 문진하여 알레르기질환 을 평가하였고, 객관적인 알레르기검사와 기관지유발검사를 시행 하였다는 강점이 있다.

결론적으로, 임신 때부터 출생 이후 12 개월 내에 반려견 또는 반 려묘를 키우는 것은 개 또는 고양이 항원 감작의 위험성을 높이고, 이에 따라 천식의 발생에 영향을 줄 수 있다. 최근 우리나라에서 반 려동물의 보유가 늘어나고 있는 실정에서, 천식의 발생을 예방하기 위해서는 임신 때부터 출생 초기에 반려동물에 대한 노출을 피하 는 것이 필요할 것으로 생각한다.

\section{REFERENCES}

1. McConnell R, Berhane K, Gilliland F, Islam T, Gauderman WJ, London SJ, et al. Indoor risk factors for asthma in a prospective study of adolescents. Epidemiology 2002;13:288-95.

2. Chan SK, Leung DYM. Dog and cat allergies: current state of diagnostic approaches and challenges. Allergy Asthma Immunol Res 2018;10:97-105.

3. Brussee JE, Smit HA, van Strien RT, Corver K, Kerkhof M, Wijga AH, et al. Allergen exposure in infancy and the development of sensitization, wheeze, and asthma at 4 years. J Allergy Clin Immunol 2005;115:946-52.

4. Anyo G, Brunekreef B, de Meer G, Aarts F, Janssen NA, van Vliet P. Early, current and past pet ownership: associations with sensitization, bronchial responsiveness and allergic symptoms in school children. Clin Exp Allergy 2002;32:361-6.

5. Lødrup Carlsen KC, Roll S, Carlsen KH, Mowinckel P, Wijga AH, Brunekreef B, et al. Does pet ownership in infancy lead to asthma or allergy at school age? Pooled analysis of individual participant data from 11 European birth cohorts. PLoS One 2012;7:e43214.

6. Chen CM, Tischer C, Schnappinger M, Heinrich J. The role of cats and dogs in asthma and allergy--a systematic review. Int J Hyg Environ Health 2010;213:1-31.

7. Chen CM, Rzehak P, Zutavern A, Fahlbusch B, Bischof W, Herbarth O, et al. Longitudinal study on cat allergen exposure and the development of allergy in young children. J Allergy Clin Immunol 2007;119:1148-55.

8. Lynch SV, Wood RA, Boushey H, Bacharier LB, Bloomberg GR, Kattan $\mathrm{M}$, et al. Effects of early-life exposure to allergens and bacteria on recurrent wheeze and atopy in urban children. J Allergy Clin Immunol 2014; 134:593-601.e12.

9. Wegienka G, Havstad S, Kim H, Zoratti E, Ownby D, Woodcroft KJ, et al. Subgroup differences in the associations between dog exposure during the first year of life and early life allergic outcomes. Clin Exp Allergy 2017; 47:97-105.

10. Jung S, Suh DI, Lee SY, Yoon J, Cho HJ, Kim YH, et al. Prevalence, risk factors and cutoff values for bronchial hyperresponsiveness to provocholine in 7-year-old children. Allergy Asthma Immunol Res 2018;10:466-77.

11. Yoon J, Choi YJ, Lee E, Cho HJ, Yang SI, Kim YH, et al. Allergic rhinitis in preschool children and the clinical utility of FeNO. Allergy Asthma Immunol Res 2017;9:314-21.

12. Crapo RO, Casaburi R, Coates AL, Enright PL, Hankinson JL, Irvin CG, et al. Guidelines for methacholine and exercise challenge testing-1999. This official statement of the American Thoracic Society was adopted by the ATS Board of Directors, July 1999. Am J Respir Crit Care Med 2000; 
161:309-29.

13. Almqvist C, Egmar AC, Hedlin G, Lundqvist M, Nordvall SL, Pershagen $\mathrm{G}$, et al. Direct and indirect exposure to pets - risk of sensitization and asthma at 4 years in a birth cohort. Clin Exp Allergy 2003;33:1190-7.

14. Collin SM, Granell R, Westgarth C, Murray J, Paul ES, Sterne JA, et al. Associations of pet ownership with wheezing and lung function in childhood: findings from a UK Birth Cohort. PLoS One 2015;10:e0127756.

15. Ownby DR, Johnson CC, Peterson EL. Exposure to dogs and cats in the first year of life and risk of allergic sensitization at 6 to 7 years of age. JAMA 2002;288:963-72.

16. Mandhane PJ, Sears MR, Poulton R, Greene JM, Lou WY, Taylor DR, et al. Cats and dogs and the risk of atopy in childhood and adulthood. J Allergy Clin Immunol 2009;124:745-50.e4.

17. Hesselmar B, Hicke-Roberts A, Lundell AC, Adlerberth I, Rudin A, Saalman R, et al. Pet-keeping in early life reduces the risk of allergy in a dosedependent fashion. PLoS One 2018;13:e208472.

18. Korea Pet Food Association. Report of pet ownership and public awarenss in 2017. Seoul (Korea): Korea Pet Food Association; 2017.

19. Ministry of Culture, Sports and Tourism. Report of pet ownership and public awarness in 2018. Sejong (Korea): Ministry of Culture, Sports and Tourism; 2018. 